\title{
PERILAKU DAN LOYALITAS KONSUMEN MADU DI KOTA BENGKULU
}

\section{CONSUMER BEHAVIOR AND LOYALITY OF HONEY IN BENGKULU CITY}

\author{
Selmi, Putri Suci Asriani, dan Rustama Saepuddin \\ Program Pascasarjana Magister Agribisnis, Fakultas Pertanian \\ Universitas Bengkulu \\ Email : selmiyunus42@gmail.com
}

\begin{abstract}
Indonesia with a current population of nearly 240 million people, is the 4th largest population in the world need quite a lot of honey. The research objective was to analyze customer characteristics honey based group of consumers, identify the attributes of honey products that affect on purchase decisions, analyze consumer behavior and customer loyalty to honey, analyze the marketing mix right is based on the analysis of consumer behavior and consumer perception of the local honey product, and formulate strategies marketing of honey in the city of Bengkulu. Determining the location of the research conducted on honey outlets in the city of Bengkulu, the selection was conducted intentionally (purposive). The location of this study were at 8 stores/outlets of honey and herbs as well as a fairly large supermarket, honey outlets which was set as the study site. Data collection was done during the months of June-August 2015. The number of respondents in this study was 96. The data collected in this research were primary and secondary data that being collected to obtain the study aims to analysis of consumer behavior is processed using Importance Performance Analysis (IPA), and analysis of loyalty consumer using the Customer Satisfaction Index (CSI). The method results Importance Performance Analysisis based on Cartesian diagram shows that there is one attribute that is considered important and is the main priority in determining customer satisfaction. The attribute was the special price for every purchase at a time/day/month special like, Ramadhan, Eid and other interest consumen calculation. Based Satisfaction Index, the level of consumer satisfaction reached $71.30 \%$ honey. The calculation results show that in general consumers of honey was categorized satisfied $(0.61<C S I \leq 0.80)$.
\end{abstract}

Keyword: Consumer behavior and loyality, Honey, Bengkulu.

\section{PENDAHULUAN}

Indonesia dengan jumlah penduduk saat ini hampir mencapai 240 juta jiwa, merupakan penduduk terbesar ke-4 di dunia membutuhkan madu yang cukup banyak. Menurut Pusat Perlebahan Nasional (2008), Indonesia memiliki tingkat konsumsi madu sekitar 15 gram/kapita/tahun, sedangkan di negaranegara maju seperti Jerman, Jepang, Inggris dan Prancis tingkat konsumsi madu 
telah mencapai 700-1.500 gram/kapita/tahun. Rendahnya konsumsi madu antara lain disebabkan karena banyaknya masyarakat menganggap bahwa madu hanya bermanfaat sebagai obat, sehingga tingkat konsumsi masyarakat Indonesia terhadap madu masih sangat rendah.

Belum terjaminnya kualitas madu oleh peternak yang banyak dijual di pasaran merupakan salah satu faktor konsumen madu dalam mengambil keputusan untuk membeli madu terutama dalam menentukan keaslian sebuah produk madu. Harga madu pun sangat bervariasi bila dilihat dari jenis maupun asal daerahnya. Hal ini akan menyebabkan kepercayaan masyarakat terhadap produk madu semakin berkurang. Madu murni yang dihasilkan di tingkat petani biasanya tidak melalui pengolahan yang baik dan hygienis, sudah terkontaminasi dan tampilan produknya pun juga tidak menarik sehingga akan berpengaruh terhadap keputusan pembelian pada konsumen madu murni di Kota Bengkulu (Rosalina dkk, 2010).

Banyaknya pesaing baru dalam bisnis produk madu terutama madu lokal dengan berbagai merek dan bentuk kemasan yang menarik serta adanya perubahan perilaku konsumen diduga akan berdampak pada preferensi konsumen dalam pembelian produk madu. Saepudin (2014), menyatakan bahwa semua merek madu kemasan yang beredar di Bengkulu dengan telah melakukan pengujian organoleptik ternyata menunjukkan kualitas yang berbeda dan kurang baik dengan kadar air yang tinggi melebihi Standar Nasional Indonesia (SNI).

Madu memiliki pangsa pasar yang luas dan prospek yang baik sehingga banyak peternak lebah madu berkompetisi dalam persaingan di bidang usaha ternak lebah madu. Produk-produk hasil lebah sangat menjanjikan jika digunakan sebagai peluang usaha. Masih banyaknya peternak lebah madu yang menjual madunya tanpa memikirkan kualitas membuat posisi petani lebah khususnya yang berskala kecil saat ini menjadi lemah. Pemasaran madu yang sering dilakukan peternak di Bengkulu adalah menjual produknya secara langsung kepada konsumen. Madu tersebut dijual secara curah/botolan yang tidak menggunakan merek dengan bentuk dan ukuran kemasan tertentu.

Berdasarkan kondisi tersebut diatas maka studi mengenai perilaku konsumen madu menjadi penting untuk dilakukan sebagai dasar pengambilan keputusan oleh pelaku bisnis. Hasil kajian dengan tujuan menganalisis perilaku dan loyalitas konsumen madu di Kota Bengkulu, diharapkan dapat menjadi salah satu solusi bagi peternak dan pelaku bisnis madu dalam rangka meningkatkan volume pemasaran produknya. 


\section{METODE PENELITIAN}

\section{Penentuan Lokasi dan Waktu Penelitian}

Penelitian dilakukan pada outlet-outlet madu di Kota Bengkulu yang dipilih melalui purposive (sengaja) dengan kriteria sebagai berikut: 1) Mudah diakses oleh masyarakat Bengkulu maupun dari luar Bengkulu; 2) Outlet-outlet yang menjual produk madu cukup banyak, dengan jenis varian lebih dari 5 macam serta persediaan dan kontinuitas barangnya ada setiap waktu; 3) Outletoutlet madu terpilih pada toko dan supermarket terbesar di Kota Bengkulu dengan penjualan/omset paling tinggi. Pemilihan outlet dilakukan berdasarkan pada survey dan wawancara, yaitu outlet yang melakukan penjualan madu dalam 1 hari minimal 5 kali. Penentuan outlet dilakukan dengan melalui survey selama 3 hari pada oulet terpilih, setelah itu jumlah omset penjualannya per bulan dirata-rata kan.

Lokasi penelitian ini dilakukan pada 8 toko/outlet madu dan herbal serta supermarket yang cukup besar di Kota Bengkulu. Pengambilan data dilakukan selama bulan Juni-Agustus 2015.

\section{Penentuan dan Pengambilan Responden}

Penentuan ukuran sampel dalam penelitian ini dilakukan dengan menggunakan rumus Virtusio. Menurut Virtusio (2004) dalam Harta (2005), metode ini digunakan karena populasi sulit diketahui lebih dahulu. Adapun rumus yang dipakai sebagai berikut :

$$
n=\frac{Z^{2}[P(1-P)]}{(M O E)^{2}}
$$

dimana $n$ adalah ukuran sampel, $Z$ adalah nilai total distribusi normal pada taraf kepercayaan 95\% adalah 1,96, $\mathrm{P}$ adalah peluang adalah 0,5, dan MOE adalah batas toleransi kesalahan $10 \%$. Jadi jumlah responden dalam penelitian ini adalah 96.

Metode yang digunakan untuk menentukan responden adalah accidental sampling. Menurut Sugiyono (2006), teknik accidental sampling adalah teknik penentuan responden berdasarkan siapa saja yang secara kebetulan dipandang cocok sebagai sumber data maka akan diberikan kuesioner. Jika orang tersebut memenuhi kriteria untuk menjadi responden maka orang tersebut diminta kesediaanya untuk diwawancarai dengan menjawab pertanyaan-pertanyaan yang ada dalam kuesioner penelitian.

Penetapan responden dilakukan secara proportional simple random sampling, jumlah dari tiap-tiap outlet madu adalah 14 responden pada outlet madu salsabila, madu herbal center Rawa Makmur 28 responden, herbal AlFatih 41 responden, 5 responden pada Apotek Faten Farma, dan pada Giant swalayan, 
outlet madu Mujtahid Pagar Dewa, Hypermart, Mini Market 88 masing-masing 3 responden. Adapun kriteria yang dijadikan sebagai responden adalah: 1) Responden berusia minimal 17 tahun yang membeli madu; 2) Responden dapat berasal dari mana saja; minimal pernah satu kali mengkonsumsi madu; 3) Responden yang dipilih merupakan pengambil keputusan dalam pembelian produk-produk kebutuhan rumah tangga, termasuk di dalamnya madu.

\section{Data}

Jenis data yang digunakan dalam penelitian ini adalah berupa data primer dan data sekunder. Data primer diperoleh melalui wawancara langsung kepada konsumen dengan mengajukan daftar pertanyaan terstruktur yang telah melalui uji validitas dan reabilitas. Sedangkan data sekunder diperoleh dari instansiinstansi yang terkait dengan penelitian ini, yaitu dari Kementrian Kehutanan, Pusat Perlebahan Madu Nasional, Asosiasi Perlebahan Madu Nasional, artikel dan penelitian terdahulu.

\section{Analisis}

Analisis perilaku konsumen diolah menggunakan Importance Performance Analysis (IPA). Menurut Martilla dan James (1977), metode IPA merupakan suatu teknik yang digunakan untuk mengukur tingkat kepuasan pelanggan dalam produk atau servicenya. Pendekatan IPA untuk mengenali kepuasan sebagai fungsi dari seberapa penting sebuah produk atau jasa buat konsumen dan performa bisnis atau perusahaan dalam penyediaan jasa atau produk.

Analisis loyalitas konsumen diolah menggunakan Customer Satisfaction Index (CSI). Metode CSI digunakan untuk menentukan tingkat kepuasan konsumen secara menyeluruh dengan melakukan pendekatan yang mempertimbangkan tingkat kepentingan dari atribut-atribut yang diukur.

\section{HASIL DAN PEMBAHASAN}

\section{Perilaku dan Kepuasan Konsumen}

Berdasarkan parameter proses keputusan pembelian konsumen, maka dapat diketahui bahwa karakteristik perilaku pembelian konsumen madu di Kota Bengkulu adalah tipe konsumen terencana. Konsumen dengan tipe terencana pada umumnya sudah memiliki pilihan merek dari produk yang akan dikonsumsinya karena konsumen seperti ini biasanya memiliki informasi yang cukup mengenai produk yang dapat memenuhi kebutuhannya. Konsumen madu mengenali kebutuhan mengkonsumsi madu sebagai pemanis atau food supplemen yang bermanfaat bagi kesehatan. Untuk itu, dalam pemenuhan kebutuhan diperlukan banyak informasi mengenai atribut produk yang mengikutinya.

16 | Selmi, Putri Suci Asriani dan Rustama Saepudin; Perilaku dan Loyalitas ... 
Alasan atau motivasi konsumen tertarik untuk mengkonsumsi madu adalah karena adanya manfaat kesehatan dari produk sebesar 83\%, 9\% alasan memiliki gaya hidup sehat sebesar $13 \%$ dan $4 \%$ kebiasaan dari sejak dulu. Dalam hal pembelian madu konsumen juga mempertimbangkan pada harga $(58 \%)$, manfaatnya bagi kesehatan sebesar $69 \%$, keasliannya 90\%. Keaslian madu secara fisik dapat dilihat berdasarkan rasa, warna, aroma dan kekentalan.

Sumber informasi yang mempengaruhi konsumen dalam pembelian madu dari diri sendiri (77\%), keluarga (15\%), teman $(7 \%)$ dan dengan alasan lainnya sebesar $1 \%$. Bentuk promosi yang membuat konsumen tertarik membeli madu adalah 56\% melalui penjualan langsung, 26\% melalui potongan harga, $12 \%$ melalui iklan/TV/media cetak dan $6 \%$ adanya hadiah melalui kemasan. Kemudian bentuk penjualan madu yang lebih disukai konsumen melalui door to door (8\%), melalui Multi Level Marketing 8\%, penjualan melalui outlet $60 \%$ dan penjualan melalui langsung dari produsen $25 \%$.

Cara konsumen memutuskan dalam melakukan pembelian madu adalah secara terencana $89 \%$, secara mendadak $5 \%$, ingin coba-coba minum madu $1 \%$ dan alasan lainnya $5 \%$. Sebanyak $98 \%$ konsumen membeli madu melakukan pembayaran secara tunai dan $2 \%$ dengan cara cash on delivery, hal ini menunjukkan bahwa harga madu yang ada di pasaran dapat di beli dan terjangkau oleh konsumen.

Peran konsumen dalam memutuskan membeli madu sebanyak $84 \%$ konsumen adalah pengkonsumsi madu. Konsumen membeli madu pada outletoutlet madu, apotik, minimarket dan swalayan. Alasan konsumen memilih tempat pembelian adalah karena lokasi dekat dengan tempat tinggal (39\%) dan lebih banyak pilihan (28\%). Jenis madu yang paling sering dibeli oleh konsumen adalah madu pahit (32\%), madu impor (22\%), madu lokal (16\%) dan madu hutan (14\%). Rasa madu yang lebih disukai oleh konsumen yaitu yang memiliki rasa manis $(68 \%)$, rasa manis keasaman sebanyak (20\%) dan memiliki rasa pahit sebanyak (12\%). Frekuensi pembelian madu pun beragam. Sebanyak 47\% konsumen membeli madu satu bulan, satu minggu sekali sebanyak $15 \%$, satu minggu dua kali sebanyak $2 \%$, kadang-kadang $18 \%$, setiap hari $1 \%$, tidak menentu sebanyak $4 \%$ dan dengan alasan lainnya sebanyak $13 \%$. Perilaku konsumen dalam mengkonsumsi madu juga beragam. Umumnya konsumen mengkonsumsi madu setiap hari sebanyak $49 \%$, seminggu 1-2 kali sebanyak $19 \%$, seminggu 3-4 kali sebanyak 18\%, sebulan sekali sebanyak 3\% dan dengan jawaban lainnya sebanyak $11 \%$. Rata-rata konsumen menghabiskan uang membeli madu sebulan antara Rp. 101.000 - 500.000,- sebanyak 54\%, dibawah 100.000 sebanyak $37 \%$, antara $501.000-1.000 .000$,- sebanyak $15 \%$ dan diatas 1 juta sebanyak 3\%. Hal ini menunjukkan bahwa madu adalah termasuk pengeluaran rutin setiap bulan disamping bahan pokok.

Pada tahap hasil pembelian madu, sebanyak $74 \%$ konsumen menyatakan bahwa harga yang dikeluarkan sudah sesuai dengan manfaat yang dirasakan, 
dan sebanyak $21 \%$ konsumen menyatakan bahwa madu yang dibeli sudah sangat sesuai dengan manfaat yang dirasakan. Tingkat kepuasan konsumen dalam mengkonsumsi madu dengan merek yang dipilih sebanyak $62 \%$ puas, $24 \%$ sangat puas, biasa saja $11 \%$ dan $3 \%$ tidak puas. Hal ini menunjukkan bahwa kepuasan konsumen dalam mengkonsumsi madu dengan merek yang dipilih sudah sangat tinggi.

Hampir semua konsumen madu loyal dan sangat bersedia menjadi pelanggan. Faktor yang mempengaruhi loyalitas konsumen terhadap atribut madu adalah karena kualitasnya (92\%). Sebanyak 55\% konsumen menyatakan bersedia menjadi pelanggan apabila madu yang dibeli telah sesuai dengan kualitasnya. Perilaku konsumen yang loyal terhadap suatu produk tentu saja akan mengguntungkan bagi produsennya karena konsumen akan terus berusaha mencari produk yang diinginkannya.

\section{Penilaian Kepentingan (Importance) dan Kinerja (Performance) Atribut Madu}

Hasil penelitian menunjukkan bahwa atribut adanya kerapian dan kebersihan tempat penjualan dari sudut pandang luar dengan nilai rata-rata tingkat kepentingan 4,32 (atribut 8). Sedangkan untuk atribut yang mempunyai nilai rata-rata terendah dengan nilai rata-rata kepentingan 3,22 adalah adanya sarana penunjang lainnya dalam ruangan (atribut 11). Atribut adanya kerapian dan kebersihan tempat penjualan dari sudut pandang luar menjadi prioritas utama adalah hal yang wajar. Ada beberapa alasan, pertama konsumen ingin melihat tempat penjualan yang terlihat rapi dan bersih yang memberikan kenyamanan bagi konsumen untuk memilih produk yang mereka butuhkan. Kedua, tempat penjualan yang rapi dan bersih akan memberikan kesan yang positif dimana konsumen dapat dengan cepat membeli produk yang diinginkan.

Selain itu, terdapat atribut yang kurang dipentingkan yaitu atribut sarana penunjang lainnya dalam ruangan seperti, wc, ruang tunggu, tempat parkir dan lain-lain yang memiliki rata-rata tingkat kepentingan paling rendah. Berdasarkan hasil penelitian, sarana penunjang dalam ruangan tidaklah begitu penting. Alasannya, karena itu bukanlah prioritas yang utama bagi mereka dalam melakukan pembelian, yang penting bagi konsumen adalah bagaimana madu yang dibeli memiliki kualitas baik dengan harga terjangkau.

Perbaikan dan peningkatan kinerja atribut pemasaran madu dapat dilakukan melalui pemetaan diagram Importance Performance Analysis (IPA). Nilai rata-rata tingkat kepentingan madu adalah 3,91 dan nilai rata-rata tingkat kinerja adalah 3,55.

\section{Perilaku Konsumen}

Diagram kartesius IPA (Gambar 1) konsumen madu di Kota Bengkulu akan menggolongkan atribut-atribut ke dalam kuadran yang sesuai. Masing-masing atribut akan menunjukkan keadaan yang berbeda. 


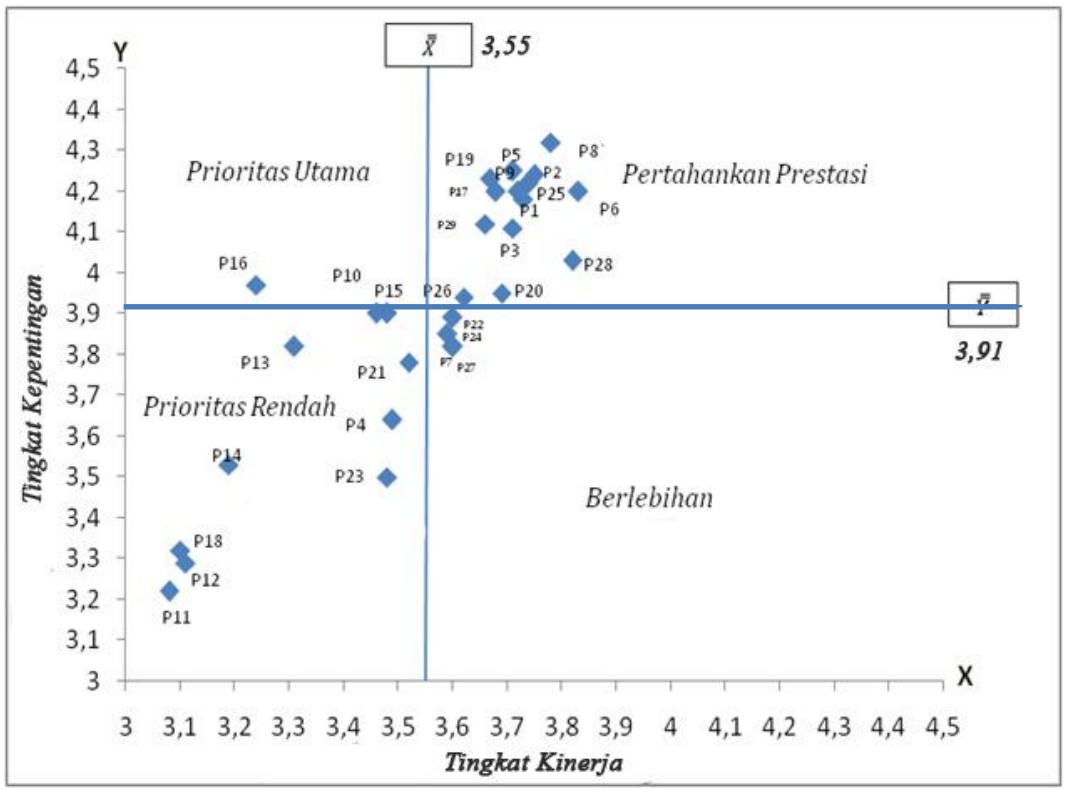

\section{Gambar 1.}

Diagram Kartesius Importance Performance Analysis (IPA) konsumen madu di Kota Bengkulu.

Sumber : Data Primer (diolah) (2015)

Berdasarkan diagram tersebut, penggolongan atribut-atribut madu ke dalam kuadran sebagai berikut :

\section{Prioritas Utama}

Konsumen Madu di Kota Bengkulu memiliki kepentingan yang tinggi terhadap atribut-atribut pada kuadran I, tetapi kinerjanya belum sesuai dan masih di bawah rata-rata. Adapun atribut-atribut yang berada pada kuadran I adalah adanya harga khusus untuk setiap pembelian madu pada waktu/hari/bulan khusus (Ramadhan, Lebaran, dan lainnya) untuk menarik minat konsumen (16). Atribut ini dinilai penting namun kinerjanya selama ini masih sangat rendah. Madu yang harganya relatif mahal jarang sekali konsumen mendapatkan potongan harga, terutama hari-hari tertentu seperti: lebaran, bulan puasa dan hari-hari lain.

\section{Pertahankan Prestasi}

Atribut-atribut yang berada pada kuadran II merupakan atribut-atribut yang dianggap penting oleh konsumen madu di Kota Bengkulu, serta secara umum telah memiliki kinerja yang baik dari produk. Atribut-atribut yang berada pada kuadran II adalah : 
1. Tersedianya informasi harga yang jelas dari keragaman produk (1). Atribut ini dinilai penting dan memiliki kinerja yang baik. Konsumen madu menilai tersedianya informasi harga yang jelas memiliki kinerja yang bagus. Harga yang jelas dari setiap keragaman produk akan memudahkan bagi konsumen dalam melakukan pembelian.

2. Adanya konsistensi harga jual guna mempertahankan pelanggan (konsumen) agar tidak beralih produk (2). Atribut ini dinilai penting dan memiliki kinerja yang baik. Harga yang konsisten menyebabkan konsumen tidak akan beralih ke produk lain.

3. Adanya konsistensi harga jual guna mempertahankan intensitas pembelian dari konsumen (3). Atribut ini dinilai penting dan memiliki kinerja yang baik. Konsistensi harga jual akan dapat mempertahankan intensitas pembelian madu.

4. Jangkauan tempat pemasaran dari produk yang mudah dijumpai (5). Atribut ini sangat penting dan memiliki kinerja yang bagus. Konsumen sangat mempertimbangkan akses dari tempat tinggalnya ke lokasi penjualan produk.

5. Tempat penjualan yang mudah terlihat dari sisi jalan guna memudahkan konsumen dalam mencarinya (6). Lokasi outlet pusat madu dinilai sangat stategis, terletak di pinggir jalan raya yang memudahkan bagi konsumen untuk mencarinya terutama bagi konsumen yang berada di Kota Bengkulu maupun luar Kota Bengkulu.

6. Adanya kerapian dan kebersihan dari tempat penjualan dari sudut pandang luar (8). Outlet-outlet tempat penjualan madu yang berlokasi di Kota Bengkulu dalam hal kerapian dan kebersihan tempat sudah sesuai dengan keinginan konsumen. Oleh karena itu, atribut ini dinilai penting dan memiliki kinerja yang baik.

7. Tata ruang produk (display) yang rapi, dan menarik (9). Tata ruang (display) madu yang dijual di outlet-outlet maupun supermarket sudah sesuai di hati konsumen. Atribut ini dinilai penting dan memiliki kinerja yang baik.

8. Pedagang memberikan potongan harga untuk konsumen yang sudah menjadi pelanggan tetap (17). Atribut ini dinilai sangat penting.

9. Pedagang memberikan potongan harga bagi konsumen yang membeli madu dalam jumlah banyak (19). Atribut ini dinilai sangat penting.

10. Adanya keragaman produk sesuai dengan khasiat/manfaat yang dibutuhkan oleh konsumen (20). Atribut ini dinilai sangat penting dan memiliki kinerja yang baik.

11. Kemasan yang menarik dan aman bagi produk (25). Atribut ini sangat penting dan kinerjanya selama ini sudah baik. Konsumen madu menilai kemasan madu sangat menarik dan bahan yang digunakan untuk kemasan sudah sesuai dengan kebutuhan konsumsi konsumen. 
12. Adanya desain kemasan dari produk untuk memenuhi keinginan konsumen (kotak, botol, bungkusan dll) (26). Atribut ini dinilai sangat penting dan kinerjanya selama ini sudah baik. Produk madu disainnya sangat praktis dengan tutup botol yang terbuat dari plastik, sehingga membuka dan menutup botol madu sangat mudah. Hasil Penelitian Rosalina, dkk (2010) menunjukkan untuk madu murni bunga kopi adalah bahan kemasan botol. Dikemas botol ada yang berukuran kecil, menengah dan besar. Disamping dikemas dalam botol plastik, madu juga dikemas dalam bentuk botol kaca.

13. Adanya rasa yang nikmat dari madu (28). Rasa madu sudah sesuai dengan selera konsumen tanpa dicampur dengan bahan lain sehingga tetap terjamin keasliaanya. Oleh karena itu atribut rasa madu dinilai penting dan memiliki kinerja yang baik.

14. Kelengkapan informasi produk yang diberikan selalu memberikan efek nyata dan efektif bagi konsumen (29). Kelengkapan informasi produk diperhatikan oleh konsumen sebelum melakukan pembelian. Kelengkapan informasi produk tertera pada kemasan madu seperti, kandungan nutrisi, manfaat, batas kadarluarsa dll. Atribut ini menjadi atribut yang penting bagi konsumen di dalam membeli madu.

\section{Prioritas Rendah}

Atribut-atribut madu pramuka yang berada pada matrik ini memiliki prioritas rendah. Konsumen Madu tidak memiliki tingkat kepentingan yang tinggi, serta pada kenyataanya kinerja atribut juga tidak terlalu istimewa. Adapun atribut yang memiliki prioritas rendah adalah:

1. Kesesuaian potongan harga terhadap kualitasnya (4). Hal ini karena menurut konsumen bentuk potongan harga terhadap kualitasnya tidak memiliki tingkat kepentingan yang tinggi, serta kinerja atribut juga tidak istimewa.

2. Penataan produk pada display sesuai jenis atau variasinya (10). Atribut ini penting karena akan memudahkan bagi konsumen untuk membeli produk yang dibutuhkannya.

3. Adanya sarana penunjang lainnya didalam ruangan (AC, kipas angin, tempat duduk, TV dll) (11).

4. Adanya ruang/ pintu masuk dan keluar khusus pada ruangan (12)

5. Adanya promosi yang gencar malalui media (cetak, massa, elektronik) (13). Tingkat kinerja atribut ini belum dikatakan baik oleh konsumen. Konsumen mengetahui informasi madu dari teman yang telah mengkonsumsi madu terlebih dahulu atau dari mulut ke mulut.

6. Adanya model/gaya promosi yang menarik dan berbeda dari promosi produk madu lainnya (14). Atribut ini memiliki prioritas yang rendah. Konsumen madu tidak memiliki tingkat kepentinganyang tinggi. Konsumen menilai bahwa promosi perusahaan belum maksimal. 
7. Promosi produk dengan pemberian informasi yang detail untuk setiap pertanyaan dari calon pembeli (15). Atribut ini menjadi atribut yang penting bagi konsumen di dalam membeli madu. Promosi dan iklan dari produk madu belum dikatakan baik oleh konsumen karena nilai kinerja atribut ini lebih rendah dibandingkan nilai kinerja rata-rata produk.

8. Adanya kejutan/hadiah yang diberikan dan informasinya tersedia pada etiket kemasan produk (18).

9. Keragaman ukuran kemasan yang dapat mempengaruhi konsumen dalam melakukan pembelian (21)

10. Banyaknya pilihan rasa yang mempengaruhi konsumen dalam melakukan pembelian (23). Madu di Bengkulu telah memberikan pilihan rasa yang cukup banyak sehingga kinerjanya baik bagi konsumen. Konsumen diberikan pilihan yang banyak dan bebas untuk memilih rasa madu apa sesuai dengan kebutuhan konsumen. Dengan demikian konsumen menilai atribut pilihan rasa sudah sangat baik namun kinerjanya tidak istimewa.

\section{Berlebihan}

Atribut-atribut yang terdapat pada kuadran ini, jika dilihat dari kepentingan konsumen berada pada tingkat kepentingan yang rendah, tetapi memiliki tingkat kinerja yang tinggi. Adapun atribut pada kuadran ini adalah:

1. Tampilan tempat penjualan yang menarik dari sudut pandang luar (7)

2. Kemasan produk dengan tampilan yang menarik dan bentuk yang praktis (22). Konsumen madu menilai kemasan madu menarik dan aman bagi produk dengan bentuk yang praktis. Kemasan botol mampu memenuhi fungsinya sebagai kemasan yang efisien dan efektif.

3. Kekentalan yang menunjukkan kandungan air yang sesuai dengan selera konsumen (24). Konsumen menilai kinerja atribut kekentalan sudah baik tetapi konsumen tidak menilai tinggi tingkat kepentingan kekentalan atribut madu sehingga kekentalan tidak menjadi pertimbangan yang penting bagi konsumen dalam membeli madu.

4. Aroma (27). Konsumen madu menilai kinerja atribut aroma madu sudah baik, namun tingkat kepentingannya rendah sehingga tidak menjadi salah satu atribut yang diperhitungkan dalam proses pembelian madu.

\section{Kepuasan Konsumen Madu}

Kepuasan konsumen madu di Kota Bengkulu secara menyeluruh ditentukan dengan mengukur CSIberdasarkan tingkat kepentingan dan kinerja dari atribut bauran pemasaran yang diukur. Berdasarkan hasil perhitungan, nilai CSI madu di Kota Bengkulu sebesar $71,30 \%$. Nilai tersebut menunjukkan bahwa secara umum konsumen madu dikatakan puas terhadap produk madu karena nilai indeks kepuasan konsumen sebesar $71,30 \%(0,7130)$ berada pada rentang 0,61 hingga 0,80 . 
Tingkat kepuasan yang dirasakan oleh konsumen madu terhadap atribut madu adalah wajar. Dari hasil wawancara, nilai kepuasan yang belum terpenuhi tersebut dapat dikarenakan perbedaan tingkat kepentingan dan kinerja terhadap atribut-atribut yang dinilai oleh masing-masing konsumen karena setiap konsumen memiliki penilaian terhadap kepentingan dan kinerja yang berbedabeda. Dengan demikian, pihak perusahaan perlu mengetahui tingkat kepentingan dan kinerja dari atribut-atribut perusahaan untuk perbaikan terhadap produk sehingga sesuai dengan kebutuhan dan keinginan konsumen madu secara keseluruhan.

\section{SIMPULAN DAN SARAN}

\section{Simpulan}

Berdasarkan hasil penelitian yang telah dilakukan, maka dapat ditarik beberapa kesimpulan sebagai berikut:

1. Karakteristik perilaku pembelian konsumen madu di Kota Bengkulu adalah tipe konsumen terencana. Dalam melakukan pembelian madu di Kota Bengkulu, konsumen memilih berdasarkan atribut pada kuadran I yaitu atributadanya harga khusus untuk setiap pembelian madu pada waktu/hari/bulan khusus (Ramadhan, Lebaran, dan lainnya). Dan atributatribut yang dianggap penting berada pada kuadran II.

2. Hasil perhitungan ini menunjukkan bahwa secara umum konsumen madu berada pada kategori puas tingkat kepuasan konsumen madu mencapai $71.30 \%$. $(0,61<$ CSI $\leq 0,80)$.

\section{Saran}

1. Produsen madu di Kota Bengkulu seharusnya dapat memenuhi atributatribut pada Kuadran I sebagai prioritas utama dan perlu memperhatikan atribut-atribut pada Kuadran II yang merupakan atribut penting.

2. Konsumen madu di Kota Bengkulu hendaknya memperhatikan atributatribut yang merupakan prioritas utama dan dianggap penting, dalam memilih produk madu yang beredar di Kota Bengkulu.

3. Produsen diharapkan bersedia menerima dan menanggapi semua keluhan konsumen agar dapat meningkatkan kepuasan konsumen.

\section{DAFTAR PUSTAKA}

Harta, Melly. 2005. Sikap dan Perilaku Konsumen Terhadap Produk Minuman Sirup Kalamansi Bukit Bengkulu di Kota Bengkulu. Skripsi Jurusan Sosial 
Ekonomi Pertanian. Fakultas Pertanian. Universitas Bengkulu. Bengkulu. (Tidak dipublikasikan).

Martilla, and James, J.C. 1977. Importance Performance Analysis. Journal of Marketing, 13-17.

Pusat Perlebahan Nasional, 2008. Lebah Madu, Cara Beternak dan Pemanfaatannya. PS. Jakarta.

Rosalina Y. Alnopri, Prasetyo. 2010. Disain Kemasan Untuk Meningkatkan Nilai Tambah Madu Bunga Kopi Sebagai Produk Unggulan Daerah. Jurnal Agroindustri 2(1) : 1-6.

Saepudin, 2014. Kualitas Madu Yang Beredar di Kota Bengkulu Berdasarkan Penilaian Konsumen dan Uji Secara Impirik. Jurnal Sains Peternakan Indonesia, 9 (1): 1-10.

Sugiyono, 2006. Statistik Untuk Penelitian, AlfaBeta. Bandung. 